\title{
The Examination of the Correlation between Scientific Attitudes And Inquiry Learning Skills in Science among Secondary School Students
}

\author{
ljlal Ocak, Gurbuz Ocak, Burak Olur
}

To Link this Article: http://dx.doi.org/10.6007/IJARBSS/v11-i1/8096

DOI:10.6007/IJARBSS/v11-i1/8096

Received: 15 November 2020, Revised: 10 December 2020, Accepted: 24 December 2020

Published Online: 11 January 2021

In-Text Citation: (Ocak et al., 2021)

To Cite this Article: Ocak, I., Ocak, G., \& Olur, B. (2021). The Examination of the Correlation between Scientific Attitudes And Inquiry Learning Skills in Science among Secondary School Students. International Journal of Academic Research in Business and Social Sciences, 11(1), 58-66.

Copyright: @ 2021 The Author(s)

Published by Human Resource Management Academic Research Society (www.hrmars.com)

This article is published under the Creative Commons Attribution (CC BY 4.0) license. Anyone may reproduce, distribute, translate and create derivative works of this article (for both commercial and non-commercial purposes), subject to full attribution to the original publication and authors. The full terms of this license may be seen at: http://creativecommons.org/licences/by/4.0/legalcode

Vol. 11, No. 1, 2021, Pg. 58 - 66

Full Terms \& Conditions of access and use can be found at http://hrmars.com/index.php/pages/detail/publication-ethics 


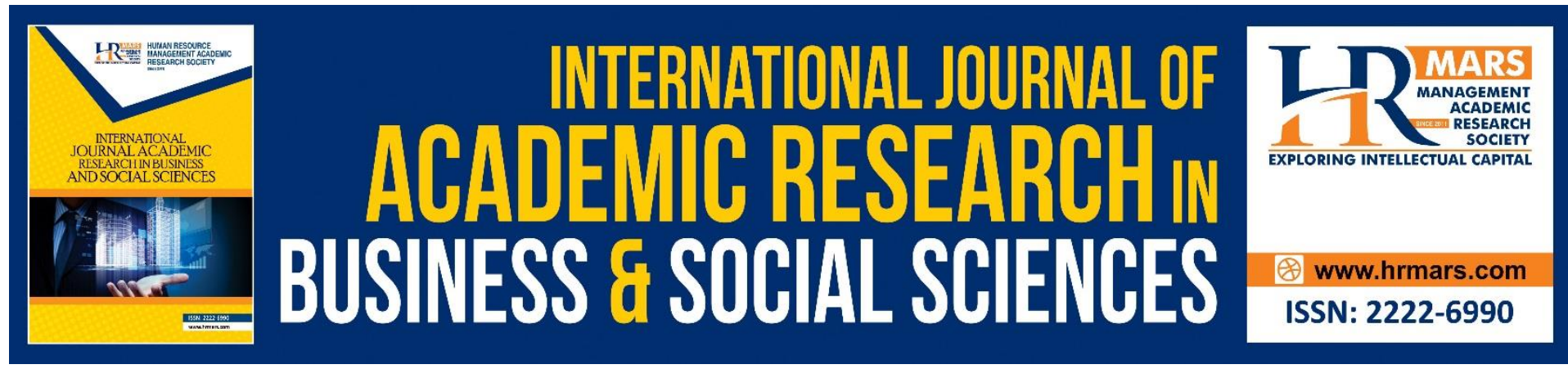

\title{
The Examination of the Correlation between Scientific Attitudes And Inquiry Learning Skills in Science among Secondary School Students
}

\author{
ljlal Ocak ${ }^{1}$, Gurbuz Ocak ${ }^{2}$, Burak Olur ${ }^{3}$ \\ ${ }^{1}$ Department of Science Teaching, Afyon Kocatepe University; ${ }^{2}$ Department of Curriculum \\ and Instruction, Faculty Of Education, Afyon Kocatepe University, ${ }^{3}$ Phd Student, \\ Department of Curriculum and Instruction, Afyon Kocatepe University
}

\begin{abstract}
The rapid development of technology and science in our time has changed the teaching activities, which is knowledge transfer of classical education systems. Today's education systems place more emphasis on student-centered approaches than teacher-centered ones. At the basis of such approaches, instead of passively passing knowledge to learners, it aims to involve students in the process, to teach them how to access information, and to make them scientific literate individuals. These approaches are aimed to provide students with the attitudes and skills necessary to solve the problems students will encounter in school and after school, not memorizing the information in the science courses. Individual attitudes are closely related to how they will behave in different situations. Individuals with scientific attitudes are expected to have a researcher and critical personality and to stay away from prejudices. The high attitudes of students towards science courses will have a positive impact on the lifetime of learning and the development of a researcher and a critical personality. The Science curriculum that is being used in our country has also been developed and put into practice on the basis of that students will construct the knowledge in their minds, that is students are in the center of the learning activity. The aim of this study is to investigate the correlation between the scientific attitude levels of secondary school students and inquiry learning perceptions. For this purpose, data were collected by using the Scientific Attitude Scale and Inqury Learning Skills for Sciece scale from 461 students who were studying in Afyonkarahisar central district in 2017-2018 academic year selected by random sampling method. As a result of the statistical procedures performed on the data, a positive correlation was found between the scientific attitude levels of secondary school students and the inquiry learning perceptions of the students.
\end{abstract}

Keywords: Scientific Attitudes, Inquiry Learning, Secondary Education

\section{Introduction}

The information age has made it necessary for societies to offer education to the individuals according to the needs of the era. Technology and science, which has been developing rapidly at an unprecedented rate, has revealed the necessity of individuals to have the characteristics to keep up with this development and to have education in a way that they can contribute to 
the development in all the required fields. Due to these requirements, curriculum are evaluated and new ones are developed in all countries to improve this feature. The curriculum are developed in such a way that individuals can take and internalize information and use this information in different environments. These features of the curriculum are very important for countries to create a solid future and to take part in the global technology and science race.

The Science and Technology curricula, which was developed and put into practice in Turkey in 2005, was developed to meet these requirements. The main aim of the curricula was determined as educating the individuals who are science literate. This curricula provided a transition from teacher-centered approaches to student-centered approaches and aimed to put the individual on the basis of learning. Science and Technology curriculum aims at inquiry learning which is one of the science literacy and constructivist approaches.

Science is a field emerging with the need of individuals to be curious about other living things formations, development and cause-effect relationships in their environment, and to try to recognize, analyze and make sense of them, and to use them in line with their own needs (Sulun \& Balki, 2009). On the other hand,the other courses related to the science aim to provide individuals with skills such as scientific thinking, as well as providing guidance for them to find answers to their questions (Yilmaz \& Soran, 1999). It is stated that inquiry, influenced by John Dewey, the constructivist philosophy and the philosophy of Soktates (Çelik, Senocak, Bayrakçeken, Taskesengil \& Doymus, 2005), has a great importance in contemporary approaches in science education as in all education fields. Furthermore, current approaches in science teaching, on the other hand, emphasize the necessity and importance of students learning science through inquiry (Ketelhult \& Dede, 2006). In fact, it can be safely said that science is a field that has emerged and developed through the inquiry. As a consequence, it is imperious to employ the inquiry-based leraning in science teaching.

In inquiry-based learning, students have an educational experience during which they learn something about the World and construct the knowledge like a scientist (Keselman, 2003). This educational experience process in inquiry-based learning focuses on the how the students get information than presenting a product or producing a solution to an existing problem (Lim, 2001). Pedaste, Maeots, Leijen and Sarapu (2012) defines this process as discovering relations by learners through hypotheses and testing the fomulated ones by experiments as well as obsevartions. Individuals find themselves in various activities during the inquiry- based learning as it requires meaningful learning, organizing information, and developing knowledge. Surely, the students should develop some abilities, according to National Science Education Standards (1996) such as asking questions, plan and conduct simple investigations, employ simple equipment and tools to gather data, use these data to construct reasonable explanations and communicate incestigations and explorations by fourth grade (Cited from Ediger, 2001). Therefore, the inquiry-based learning requires a more student-based leraning activities designed to make the students face with real life problems.

As stated that the students should be active during the science learning, it is also necessary that the students do not memorise the scientific information but they need develop attitudes and cognitive skills which are vital to solve the real life problems they encounterd (Demirbas \& Yagbasan, 2005; Khalid, 2020). There are cognitive, affective and behavioral characteristics of the attitude that is related to how individuals behave in different situations (Safran, 1993). Scientific attitude, which has a dominant cognitive aspect, is defined as the ability of the individual to interpret the problems, events and situations they encounter independently of their own subjective thoughts and feelings (Basaran, 1978). Hence, the 
scientific attitudes directly have an effect on students' science learning. As stated by Juhji \& Nuangchalerm (2000) the interaction between the scientific attitudes and skills during the scientific process are correlated in science learning. Furthermore, the scientific attitude is closely grounded on knowledge, belief, or mindset in responding to knowledge. In order to help the students to develop scientific attitudes, it is inevitable to somehow includem the in the teaching and learning process by employing more student-based activities.

When examined the literature, there are studies on inquiry based learning indicating that this method helps to prolong the duration of keeping the information in the mind (Akpullukçu \& Gunay, 2013), helps to develope more positive attitudes to science lesson (Bozkurt, 2013) and inquiry skills (Chen \& Chen, 2012). There are also studies indicating that the students with high scientific attitudes are better at science process skills (Mahulae, Sirait \& Sirait, 2017), high positive scientific attitudes helps students to understand the concept of natural science easily (Puspita, 2018). It is clear that individuals with scientific attitudes are expected to have investigative, critical features and are free from prejudices. Scientific attitudes of individuals will closely affect their inquiry learning skills towards science. It is crucial to determine the students' attitudes to take action to develop new way to get them involved in the learning process. Surely, it is also important to enlightened the scientifc ability of thes students in order to determine the need to shape the the desired outcomes. For these reasons, the research will determe the level of scientific attitudes and inquriy learning skills of primary school students in science teaching and revealing the correlation between these two variables. So, the aim of the study is to examine the correlation between primary school students' attitudes towards science teaching and their inquiry learning skills towards science. For this purpose, the following research problems have been created:

1. What is the scientific attitude level of secondary school students?

2. What is the inquiry learning perception level of secondary school students?

3. Is there a significant correlation between secondary school students' scientific attitude levels and their inquiry learning perceptions?

4. Do secondary school students' scientific attitude levels predict their inquiry learning perception?

\section{Method}

In this study aiming to reveal the secondary school students' scientific attitude level and inquiry learning perceptions and the correlation between these two variables, correlational survey model has been employed.

Sample and Universe

The universe of the study consists of the secondary school students studying in Afyonkarahisar Province in Turkey studying in various schools in the spring term of 2017-2018 academic year. The sample of the study consists of 461 students selected by simple random sampling method. Demographic information about the sample is given in Table 1. 
Table 1. Demographic information of the sample

\begin{tabular}{llcc}
\hline \multicolumn{1}{c}{ Variables } & & $f$ & $\%$ \\
\hline \multirow{3}{*}{ Gender } & Female & 245 & 53,1 \\
& Male & 216 & 46,9 \\
& Total & 461 & 100 \\
\hline \multirow{4}{*}{ Grade } & 5 & 102 & 22,1 \\
& 6 & 99 & 21,5 \\
& 7 & 128 & 27,8 \\
& 8 & 132 & 28,6 \\
& Total & 461 & 100 \\
\hline
\end{tabular}

\section{Data Collection Tools and Data Analysis}

Two scales were used in the study. In the study, "Scientific Attitude Scale" developed by Moore and Foy (1997) and adapted to Turkish by Demirbas and Yagbasan (2006) was used to determine the level of scientific attitudes of the participants, namely students. As a result of the adaptation of this scale, the original of which consists of 60 items, to Turkish, the number of items was determined as 40 and 6 sub-dimensions (1. The structure of scientific laws and theories, 2. The structure of science and its approach to events, 3. Displaying scientific behavior, 4 . The structure and purpose of science, 5 . The place and importance of science in society, 6 . Willingness to do scientific studies) The Cronbach Alpha reliability coefficient of the scale was .76 and the Spearman Brown split half-test correlation was .84. The high score in the scale indicates high level of attitude. "Inquiry Learning Skills Perception Scale in Science" developed by Balim and Taskoyan (2007) was used to determine the participants' perceptions of inquiry learning skills towards Science. The scale consists of 22 items and 3 sub-dimensions: (1) positive perceptions, (2) negative perceptions, and (3) perceptions of questioning truthness. The Cronbach alpha coefficients of the sub-dimensions of the scale were .67, .73, .71 , respectively; The total Cronbach alpha reliability coefficient of the scale was calculated as .84. The high score in the scale indicates high level of perception.

In the analysis of the data, firstly, Kolmogorov-Smirnov test was used to determine whether the scale used was normally distributed or not. Data were not normally distributed ( $p>$.05). Therefore, the parametric tests, descriptive analysis, Pearson correlation analysis and regression analysis, have been employed.

\section{Findings}

In this part of the study, in line with the sub-problems of the research, first of all, the scientific attitude levels of secondary school students and inquiry learning perception level of the secondary school students were determined. Then, the correlation and regression analysis between these two variables have been calculated.

The first sub-problem of the study 'What is the scientific attitude level of secondary school students?' is given Table 2. 
Table2. The Scientific attitude level of secondary school students

\begin{tabular}{lcc}
\hline Scale and Subdimensions & $\overline{\mathrm{x}}$ & ss \\
\hline The structure of scientific laws and theories & 20,68 & 3,05 \\
The structure of science and its approach to events & 19,19 & 2,98 \\
Displaying scientific behavior & 20,41 & 2,44 \\
The structure and purpose of science & 22,58 & 4,02 \\
The place and importance of science in society & 18,91 & 3,05 \\
Willingness to do scientific studies & 34,79 & 5,10 \\
Total & 136,59 & 13,13 \\
\hline
\end{tabular}

As seen, in the Table 2. the mean value of the secondary school students regarding the subdimensions of the scale is at the moderate level (respectively, $\bar{x}=20,68, \bar{x}=19,19, \bar{x}=20,41$, $\bar{x}=22,58, \bar{x}=18.91$ and $\bar{x}=34.79$ ). When the general score the students got from the scale was examined, it was concluded that the students showed a moderate level of attitude as they had shown in the other sub-dimensions of the scale.

The second sub-problem of the study 'What is the inquiry learning perception level of secondary school students?' is given Table 3 .

Table 3. The Inquiry learning perception level of secondary school students

\begin{tabular}{lcc}
\hline Scale and Subdimensions & $\overline{\mathrm{x}}$ & ss \\
\hline Positive Perceptions & 3,95 & .654 \\
Negative Perceptions & 3,52 & .724 \\
Inguiry the Truthness & 3,81 & .765 \\
Total & 3,79 & .560 \\
\hline
\end{tabular}

As seen in the Table 3. the mean value of the secondary school students regarding the subdimensions of the scale is at the moderate level (respectively, $\bar{x}=3,95, \bar{x}=3,52, \bar{x}=3,81$ ); and the the mean value of the secondary school regarding the total scale ise also at the moderate level $(\bar{x}=3,79)$. However, these mean values are near to the high level.

The third sub-problem of the study 'Is there a significant correlation between secondary school students' scientific attitude levels and their inquiry learning perceptions?' is given Table 4.

Table 4. The correlation between secondary school students' inquiry learning perceptions and scientific attitudes

\begin{tabular}{lcc}
\hline & Correlation Coefficient & $p$ \\
\hline Inquiry Learning & .536 & .000 \\
Scientific Attitudes & .500 & \\
\hline
\end{tabular}

Correlation analysis, which was conducted to reveal whether there is a statistically significant relationship between the inquiry learning perceptions and scientific attitudes of the secondary school students, revealed that there is a significant $(p<.05)$ and a positive correlation at the moderate level $(r=.536)$ between the two variables. 
The fourth sub-problem of the study 'Do secondary school students' scientific attitude levels predict their inquiry learning perception?' is given Table 5.

Table 5. Predictive role of scientific attitude on inquiry learning perceptions.

\begin{tabular}{|c|c|c|c|c|c|c|}
\hline & & $\begin{array}{l}\text { Sum of } \\
\text { squares }\end{array}$ & Df & $\begin{array}{l}\text { Mean of } \\
\text { Squares }\end{array}$ & $\mathrm{F}$ & $p$ \\
\hline Regression & & 9882,056 & 1 & 9882,056 & 124,41 & .000 \\
\hline Constant & & 24464,963 & 308 & 79,432 & & \\
\hline Total & & 34347,019 & 309 & & & \\
\hline $\mathrm{R}=.536$ & $\mathrm{R}^{2}=.288$ & Adj. $R^{2}=.285$ & & & & \\
\hline
\end{tabular}

Simple regression analysis were done to see if scientific attitude was a statistically significant predictive of inquiry learning perception and the results show that there is a significant correlation between two variables $\left(R=.536 ; R^{2}=.288\right)$ and the results also reveals that the scientific attitudes is an important predictive of inquiry learning perception $(F=124,41, p<.05)$.

\section{Results and Discussion}

As a result of the research, it has been concluded that primary school students have a moderate scientific attitude. It has been concluded that they have showed an attitude level slightly above the moderate level, the mean values are $\bar{x}=20,68, \bar{x}=19,19, \bar{x}=20,41, \bar{x}=22,58$, $\bar{x}=18.91$ and $\bar{x}=34.79$, respectively. When the overall mean value of the students got from the scale has been examined, it has been concluded that the students has showed a moderate level of attitude. This result of the study is similar to the study of Ata (1999). In the study, the scientific attitude levels of primary school 2nd grade students were measured and it was concluded that the students had a moderate level scientific attitude. Students' moderate scientific attitude can also be interpreted as their indifference to courses such as science, chemistry, physics and biology. In order to increase the scientific attitudes of the students, the curriculum of these courses should be arranged in a way to encourage scientific attitudes. In the research conducted by Chuang and Cheng (2002), a significant result was found in favor of female students. The scientific attitude may also differ depending on the structure of the countries where the studies were conducted. It is natural for male students to have a higher scientific attitude, as engineering and technology related fields are generally associated with male students in our country. Demirbas and Yagbasan (2005) revealed in their study that the grade variable has an effect on students' scientific attitudes and that eighth grade students have higher scientific attitude scores than sixth grade students. It is an expected result that the students will show a higher level of scientific attitude as they reach the objectives of the scientific courses in line with the objectives of the curriculum in the following years.

Secondary school students' perceptions of inquiry learning are at medium level in the subdimensions of the scale and throughout the scale. The students obtained the highest score from the positive perceptions sub-dimension of the scale $(X=3.95)$. Tatar (2006) concluded that students' inquiry learning perceptions were low and emphasized the need to increase this perception. The scores obtained from the students as a result of the research showed that their inquiry learning perceptions were at a level which needs to be improved.

The simple correlation, which was made to reveal whether there is a statistically significant correlation between the inquiry learning and scientific attitudes of middle school students, revealed that there is a significant $(p<.05)$ and a positive relationship $(r=.536)$ between the two variables. The results of the study are also similar to the results of the research conducted 
by Taskoyan (2008). As a result of the research, it was stated that there was a positive relationship between students' scientific attitudes and their inquisitive learning perceptions, and it was emphasized that this relationship was also related to the methods and techniques used in the lessons. Simple regression, which was performed to determine whether the scientific attitudes of middle school students were a predictor of their inquiry learning, showed that there was a moderate relationship between the two variables $(R=.536 ; R 2=$ .288); secondary school students' scientific attitudes are an important predictor of their inquiry learning perceptions $(F=124,41 ; p<.05)$. Secondary school students' scientific attitudes predict $28 \%$ of their inquiry learning perception. This result of the study is similar to the result of Chen and Chen (2012). As a result of the study, they stated that scientific attitudes predict a certain rate of inquiry learning perceptions, but classroom practices also have an important place at this predictive level. So, it is advised that the the activities that promote the student engagement should be used to increase the students' scientific attitudes and inquiry learning perception.

The moderate scientific attitude level of the secondary school students towards to science has revealed a fact that the desired outcomes of the science curriculum has not been reached. So, the classroom activities should be concentrate on more students-based activities that promote high scientific attitudes. Inquiry learning perceptions level of the students has pointed out the same results as reached in the scientific attitudes. This has showed that the inquiry learning perception as reached in the study is closely related and affected by students attitudes. So, the science curriculum should be developed and implemented to increase the students attitudes to be able to increase their inquiry learning perception and vice versa.

\section{References}

Akpullukcu, S., \& Gunay, Y. (2013). Fen ve teknoloji dersinde arastirmaya dayali ogrenme ortaminin ogrencilerin akademik basari, hatirda tutma duzeyi ve tutumlarina etkisi, Ege Egitim Dergisi, 14 (1), 67-89.

Ata, E. (1999). Illkogretimde bilimsel ve sosyal tutum adapazari ornegi. Sakarya Universitesi, Sosyal Bilimler Enstitusu, Yuksek Lisans Tezi.

Balim, A. G., \& Taskoyan, S. N. (2007). Fene yonelik sorgulayici ogrenme becerileri algisi olçegi'nin gelistirilmesi. Dokuz Eylul Universitesi Buca Egitim Fakultesi Dergisi, (21).

Basaran, I. E. (1978). Egitim psikolojisi. Ankara: Bilim Matbaasi.

Bozkurt, O., Ay, Y., \& Fansa, M. (2013). Arastirmaya dayali ogrenmenin fen basarisi ve fene yonelik tutuma etkisi ile ogretim surecine yonelik ogrenci gorusleri. Abant izzet Baysal Universitesi Egitim Fakultesi Dergisi, 13, (2), 242-256.

Chen, C., \& Chen, C. (2012). Instructional approaches on science performance, attitude and inquiry ability in a computer-supported collaborative learning environment. TOJET: The Turkish Online Journal of Educational Technology, 11, (1),113-122.

Chuang, H. F., \& Cheng, Y. J. (2002). The relationships between attitudes toward science and related variables of junior high school students. Chinese Journal of Science Education, 10, (1), 1-20.

Çelik, S., Senocak, E., Bayrakçeken,S., Taskesenligil,Y., \& Doymus,K.(2005). Aktif ogrenme stratejileri uzerine bir derleme çalismasi. Kazim Karabekir Egitim Fakultesi Dergisi, 11, 156-185.

Demirbas, M., \& Yagbasan, R. (2006). Fen bilgisi ogretiminde bilimsel tutumlarin islevsel onemi ve bilimsel tutum olçeginin Turkçe'ye uyarlanma çalismasi. Uludag universitesi egitim fakultesi dergisi, 19(2), 271-299. 
Ediger, M. (2001). Assessing: Inquiry Learning In Science. http://eric.edu.gov.tr.

Juhji, J., \& Nuangchalerm, P. (2020) Interaction between scientific attitudes and science process skills toward technological pedagogical content knowledge J. Educ. Gift. Young Sci. 8, 1-16.

Keselman, A. (2003). Supporting inquiry learning by promoting normative understanding of multivaiable causality. Journal of Research in Science Teaching, 40(9), 898-921.

Ketelhult, D. J., \& Dede, C. (2006). "Assessing inquiry learning." http://muve.gse.harvard.edu/rivercity.project/documents/lettersnarst2006paper .pdf mayis 2006.

Khalid, N. (2020). Artificial intelligence learning and entrepreneurial performance among university students: evidence from malaysian higher educational institutions. Journal of Intelligent \& Fuzzy Systems, (Preprint), 1-19.

Lim, Byung-Ro. (2001). Guidelines for designing inquiry-based learning on the web: online professional development of educators. Doktora Tezi. Indiana University.

Mahulae, P. S., Sirait, M., \& Sirait, M. (2017). The effect of inquiry training learning model using PhET media and scientific attitude on students' science process skills. IOSR Journal of Research \& Method in Education.

National Research Council. (1996). National science education standards. Washington, DC: National Academy Press.

Pedaste, M., Maeots, M., Leijen, A., \& Sarapuu, T. (2012). Improving students' inquiry skills through reflection and self-regulation scaffolds. Technology, Instruction, Cognition and Learning, 9 (1-2), 81-95.

Puspita, D. M. (2018). The Effect of Discovery Learning Model and Scientific Attitude of Students on the Understanding of the Concept of Natural Science in Students of Grade IV Primary School. In 3rd Annual International Seminar on Transformative Education and Educational Leadership (AISTEEL 2018). Atlantis Press.

Safran, M. (1993). Degisik ogretim basamaklarinda tarih dersine iliskin tutumlar uzerine bir arastirma. Gazi Egitim Dergisi, 4, 35-40.

Sulun, A., \& Balki, N.(2009). Turkiye'de fen ve teknoloji egitimi ve kultur. Erzincan Universitesi, Egitim Fak. Dergisi, 1, (1), 87-100.

Taskoyan, S. N. (2008). Fen ve teknoloji ogretiminde sorgulayici ogrenme stratejilerinin ogrencilerin sorgulayici ogrenme becerileri, akademik basarilari ve tutumlari uzerindeki etkisi (Doctoral dissertation). DEU Egitim Bilimleri Enstitusu.

Yilmaz, M., \& Soran, H. (1999). Illkogretimde degisen egitim sistemlerinin biyoloji dersine etkileri. Hacettepe Universitesi Egitim Fakultesi Dergisi, 17, (17), 178-188. 